\title{
Tourists' Motivation to Travel to Boracay amidst COVID-19 Pandemic
}

\author{
Agapito, Ellaine Joy J, Cunanan, Maria Patricia M, Oabel, Kathlene Antonette SJ*, Ms. Irene \\ Gueco \\ De La Salle University - Dasmariñas College of Tourism and Hospitality Management
}

*Corresponding Author: Oabel, Kathlene Antonette SJ, De La Salle University - Dasmariñas College of Tourism and Hospitality Management

\begin{abstract}
Ever since the COVID-19 pandemic was made known to the world, it brought challenges to its people and its economic development. The Tourism and Hospitality Industry has been greatly affected as the global travel restriction has been implemented, due to this reason the researchers aimed to help the industry to bounce back amidst pandemic. The study determined the willingness of tourists to travel amidst pandemic through the push and pull travel motivators, along with the guidelines and protocols set by the government agencies. The destination used in this study was Boracay Island as it is one of the first tourism bubble that was reopened by the Department of Tourism in the Philippines that requires travel and safety protocols. The push and pull theory were used in the study and was modified to identify the factors and incorporated the protocols to meet the needs of the study. The research design of the study is exploratory research, since the issues and solutions are still developing and to support the study, secondary research was used. To further investigate on how the push and pull travel motivators affect the decision of a traveler, the researchers used the tools such as: purposive sampling method and conducted an online survey with the use of Google Forms that was disseminated to the College of Tourism and Hospitality students of De La Salle UniversityDasmariñas through social media platforms. The data was processed and analyzed using the chi-test square. The results show that there is no significant relationship between the demographic profile of the respondents and the push and pull travel motivational factors, but there is a significant relationship between the willingness to travel on both push and pull motivation factors, as well as the duration of stay that show in the pull motivators.
\end{abstract}

Key words: Boracay, COVID-19, pandemic, tourism, push and pull travel motivators, tourists' motivation

\section{INTRODUCTION}

Prior to the COVID-19 pandemic, the ${ }^{[1]}$ World Travel and Tourism Council (2019), made an Economic Impact Report in 2019 where it was stated that the travel and tourism sector has reached $3.5 \%$ growth surpassing the global economy growth of $2.5 \%$ over the past nine years. Through the 330 million jobs it contributed to the $10.4 \%$ of the global Gross Domestic Product, it garnered a total of $6.8 \%$ total exports and $27.4 \%$ of global services exports. However, when Coronavirus Disease 2019 began its outbreak on December 31, 2019 in Wuhan, Hubei Province in China. The World Health Organization established a global pandemic status for COVID-19 at the beginning of March 2020 due to its rapid proliferation, the COVID-19 is caused by the SARS-CoV-2 virus, which spreads through close contact with another person ${ }^{[2]}(\mathrm{WHO}, 2020 \mathrm{~b})$. Also, it can be transmitted by an infected person's mouth or nose in small liquid particles. It may be through coughing, sneezing, speaking, singing, or breathing heavily ${ }^{[3]}$ (Martin, 2020).

As the world faces the challenges of the COVID-19 pandemic, the tourism and hospitality industry were not able to escape from its drastic impacts. It became one the most affected industries due to the global travel restrictions in order to reduce the risk of spreading the virus. The decrease in tourist demand, resulted in flight cancellations, temporary closure of tourism destinations and establishments, and employee retrenchment. According to the United Nations World Tourism Organization almost $96 \%$ of destinations worldwide introduced travel restrictions and implemented preventive measures to confine the virus in their respective countries and reduce the risk of infecting others ${ }^{[4]}$ (UNWTO, 2020a).As of April 6, 2020, about 43\% are completely/partially closed its borders for tourists coming from the countries that are infected by the virus, $27 \%$ have suspended some international flights, $21 \%$ 
have implemented travel bans to passengers coming from certain destinations affected by COVID-19, while the remaining 9\% have different measures in implementing the restrictions ${ }^{[5]}$ (UNWTO, 2020b). Aside from travel restrictions, UNWTO also stated that international tourist arrivals decreased by $82 \%$ in the Asia and Pacific region, 73\% in the Middle East, 69\% in Africa, and 68\% in both America and Europe. Although, it is stated that domestic tourism in China and Russia are back to pre-COVID levels ${ }^{[6]}$ (UNWTO, 2020c). Given that months passed by some countries are slowly recovering from the economic impacts that the COVID-19 pandemic caused and gradually restarting their travel bubble.

After COVID-19 was declared as global pandemic in March 2020, major destinations adjusted their travel restrictions, implemented "lockdown" policy, and became stricter in their approach to reduce the spread of the virus. The ${ }^{[7]}$ World Health Organization (2020a), implemented a variety of preventive measures worldwide such as, protocols in social distancing which includes mass gathering, unnecessary travels, suspension of school classes, and overcrowding, as well as strictly following the health protocol and safety standards. In compliance with the World Health Organization guidelines to suppress further transmission of the virus, the Philippine Government declared the "Bayanihan to Heal as One Act" under the Republic Act No. 11469 due to the existence of a national emergency in the country. This allows the president to exercise powers necessary and proper to carry out the declared national policy ${ }^{[8]}$ (Congress of the Philippines, 2020).

Boracay Island being one of the first tourism destinations to reopen in the Philippines amidst pandemic, the Department of Tourism, Department of Environmental and Natural Resources, Department of the Interior Local Government, the Province of Aklan and the Municipality of Malay had an agreement on the reopening of Boracay Island to the domestic tourists wherein they would be lifting the age restriction policy ${ }^{[91}(D O T, 2020 a)$. Moreover, visitors ages below 21 and above 60 years old are allowed provided that they have no underlying medical conditions and a negative RTPCR test result. According to the Department of Tourism, tourists must have a confirmed booking on DOT-accredited accommodation establishment, airline ticket, and tested negative to the RT-PCR test within 48-72 hours prior to their travel. This shall be submitted online for the approval of the Aklan Provincial Government. Tourists from MGCQ, GCQ, and NCR areas are allowed to visit Boracay Island as long as tourists have a negative RT-PCR test. Tourists must follow the minimum health protocols such as: wearing masks, observing one-meter social distancing, and proper hygiene ${ }^{[10]}$ (DOT, 2020b). In addition, travelers to Boracay will have their own QR Code, which monitors their movement and activities on the Island for an easy contact tracing. However, in case there would be guests who exhibit symptoms of COVID-19, DOT-accredited accommodation establishments have a designated health and safety officer who will call Boracay COVID hotline number 152 and through their QR code system will be used to identify who had a close contact on the person who tested positive on the virus ${ }^{[9]}(D O T, 2020 a)$.

Given the fact that Boracay Island is one of the first tourism destinations that has been reopened after the strict implementation of community quarantine dated June 16, 2020, when the Boracay InterAgency Task Force decided to reopen its doors for tourists residing in Western Visayas region, where they have a total of 5,026 visitors dated from June 16 to September 30, 2020 ${ }^{[111}$ (Yap, 2020). Furthermore, on the statement released by the ${ }^{[12]}$ Office of the Presidential Spokesperson $(2020 a)$, the IATF Resolution No. 74 implements that Boracay Island may accept tourists from areas under General Community Quarantine or lower, this enactment is effective on October 1, 2020. The Island expects to have an average of 50 visitors a day. According to an article released by Inquirer, from 0ctober 1 to 29, Boracay Island received a total of 2,337 visitors, while November 1 to 17 has a total of 1,611 tourists visited the destination ${ }^{[13]}$ (Burgos Jr., 2020). In addition to that, since the community quarantine loosen up a bit the Island has an average number of 300 to 400 visitors a day with a total number of 11,898 visitors in January 2021 alone. Also, to support the study, the forging of RT-PCR test results arises, which somehow shows that there are still people who are willing to travel amidst pandemic even with the several documents needed before entering the province ${ }^{[14]}(D O T, 2021)$. In 2019, there is a record of 2,034,599 visitors presented by Malay Aklan Municipal Tourism Office ${ }^{[15]}$ (Zabal, 2020), the number of tourist arrival prior to COVID-19 pandemic significantly dropped compared to the data mentioned above which most likely to happen in observance with the travel ban, lockdown, and safety protocols implementation. 
The research gap of study is how the safety protocols issued by the Inter-Agency Task Force, Department of Tourism, Department of Transportation, and the Local Government Units affects the travel decision of tourists, specifically some of the Tourism and Hospitality students of De La Salle University - Dasmariñas and ensure motivational factors that will encourage tourists to travel even amidst a pandemic. Moreover, it is known that the COVID-19 pandemic is still an on-going crisis up to this date, whereas the scope of this study will only focus on a specific duration from December 2019 to February 2021.

\subsection{Research Questions:}

1. What is the demographic profile of the respondents in terms of:

1.1 Age

1.2 Gender

1.3 Course

1.4 Year/Level

1.4 Number of trips per year

1.5 Willingness to travel amidst the pandemic

1.6 Willingness to travel to Boracay

1.7 Intended number of nights to stay in a destination.

2. How do the respondents assess the motivation to travel in terms of:

2.1 Push travel motivations factors

2.2 Pull travel motivations factors

\section{Hypothesis}

Is there a significant relationship between the profile of the respondents and their assessment on the travel motivation factors?

The significance of the study is to determine if the guidelines are enough to ensure the safety of tourists to travel amidst pandemic and how these factors affect the decision of the tourist to visit the destination. This study could benefit future researchers to support their study as it is relevant to the current situation of many countries. The pandemic has still a long way to go, and protocols are still progressing, thus this study could still grow in the future.

\section{Literature REVIEW AND CONCEPTUAL/THEORETICAL FrameWORK}

The severe acute respiratory syndrome (SARS) epidemic of 2003 is the most correlated disease outbreak of the current COVID-19 pandemic. Although COVID-19 has a lower mortality rate compared to SARS that has a $10 \%$ mortality rate, it circulates across the globe, unlike the SARS where it has been contained relatively soon ${ }^{[161}(B M J, 2020)$. Thus, both viruses caused a global setback wherein countries have dealt with global travel restrictions and lockdowns to restrain the virus that affects the world economy. A research study by Wachyuni and Kusumaningrum ${ }^{[171}(2020)$ claimed that due to the COVID-19 pandemic, people's preferences to travel changed concerning the willingness to travel after the pandemic, the type of tourism of choice, preferred destination aspects, planned tours after the outbreak, and interest in visiting destinations with or without a history of corona affected patients. They found that $(78 \%)$ of respondents are willing to travel after the pandemic ends, $(66 \%)$ preferred nature tourism, and the destination aspects priorities are $(73 \%)$ safe, (64\%) clean, (62\%) beautiful, (52\%) cool, (44\%) suave, and (42\%) memorable. Moreover, $(31 \%)$ strongly agrees to have planned a tour after the pandemic ended, and (37\%) disagrees with visiting a

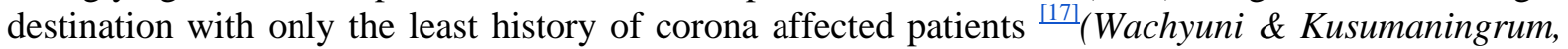
2020). Change is inevitable, and so are individual's personal choices, which in various tourist motivation studies, can also be categorized into push and/or pull motives.

${ }^{[18]}$ Said and Maryono (2018) reported that the analysis method has been used to justify the reason why push and pull factors motivate the tourists to decide in which destination they want to visit and experience the type of activity they want. They also stated that push factor motivation can be 
identified into environment or climate, relaxation, adventure and personal. Meanwhile, pull factor motivations are defined through visitors' emotional, product, service, and cognitive dissonance satisfaction. Tourists should classify their alternatives in choosing a destination based on several criterias, such as self-motivation (push factor), domination perception of tourists from the destination (pull factor), and the availability of money and time (situational constraints) ${ }^{[181}$ (Said \& Maryono, 2018). Analyzing what stimulates a person's desires and decisions in visiting and/or exploring tourist destinations creates a detailed standard model that helps tourism marketers improve their products and services.

Individuals' travel patterns and preferences are closely related to their psychological patterns, which can be assessed to study the motivations ${ }^{[19]}$ (Qiu et al., 2020, as cited in Roy, G. and Sharma, S., 2020), wherein, push and pull motivation factors play an important role in stimulating the decisionmaking process of an individual to travel to their desired tourist destination. There are five stages of tourist behavior to consider, which are: 1) the tourist recognizes the need for tourism; 2) tourist collects information related to tourism; 3 ) tourist determines the tourist decision, which is followed by a tour; 4) and the last stage evaluates the tourist trip that has been carried out ${ }^{[17]}$ (Mathieson A., Wall G., 1982, as cited in Wachyuni \& Kasumaningrum, 2020). Although given the patterns and motivations mentioned above, the perceived health risk of people during the spread of the coronavirus outbreak may develop fear and anxiety ${ }^{[20]}$ (Zheng, Luo \& Ritchie, 2021), which may affect the decision of tourists to travel.

From the various research studies mentioned above, several factors affect and influence individuals' decision in selecting destinations they visit. It determines personal preferences, which was analyzed in this study among the selected participants. However, as infectious disease was introduced there has been changes on the motivation ng tourists wherein, they focus on the safety, unlike before where they chose to travel just for the scenic view and/or for leisure and recreation purposes only. This study correlates with the past research as they both present similar ideas in distinguishing what motivational factors influence the decision of tourists to travel. In contrast with that, since the study is still ongoing with the emerging variants of the viruses, the tourists became more fearful and conscious in ensuring the safety of themselves, as well as the safety of their family, are some of the factors that influence their decision to travel amidst pandemic.

\section{CONCEPTUAL FraMeWORK}

Dann's 1977 theory of push and pull has been widely used as a framework in studying and determining tourists' motivation to travel. His theory suggests that people travel because of their internal desires (push) and external factors (pull) a destination has. Push factors or internal desires can be identified as the longings for relaxation, rest, leisure, recreational activities, and/or a break from the

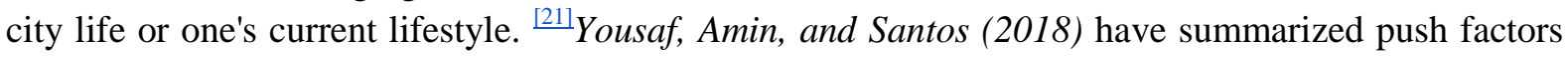
as the socio-psychological needs of people that encourage them to travel. On the other hand, pull factors are the qualities of the destination that an individual looks for. For example, the fine white sand and crystal-clear water of beaches, the amenities of a hotel, the prices of a one-day stay in a resort, the services offered in a restaurant, and other features a place and/or destination could provide the tourists. In the simplest form, push motivational factors are 'the desire to travel', while the pull motivational factors are 'the choice of destination' ${ }^{[22]}$ (Crompton, 1979). These motivational forces help the local tourism sectors analyze the reasons why tourists prefer (or not prefer) to visit certain attractions ${ }^{[23]}$ (Zhang \& Marcussen, 2007).

This study is not a replication of the study from various researchers mentioned, however this will be used as a concept in the study. The push and pull theory will be used as the basis for this research study wherein the demographic profile will serve as an independent variable that affects the push and pull motivations of travelers. Moreover, the protocols, guidelines, and memorandum implemented by the Philippine government such as; the tourists who will travel must follow the minimum health standard and safety protocols such as maintaining 1-meter social distancing, and wearing of face masks and face shields, to reduce the transmission of the virus could influence the decision of the demographics in terms of their travel motivation. 


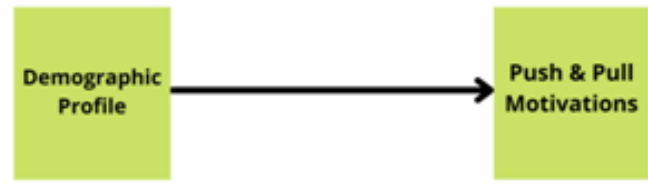

Figure1. Conceptual Framework

\section{Methodology}

The researchers will be using an exploratory research design for the study. This type of research design is chosen as an appropriate means of obtaining the data because the researchers seek to explore, analyze, and evaluate tourists' travel motivation using the push and pull theory along with the IATF protocols and guidelines to have a better understanding of how the pandemic affects travel decisions. The researchers came up with the survey questionnaire that will be distributed to the chosen respondents, wherein the protocols issued by the IATF, DOT, and DOH are incorporated in the push and pull factors to know and understand the motivation factors that affects the willingness of the respondents to travel during this time of pandemic.

The respondents of the study are the first year to third year college students of De La Salle UniversityDasmariñas taking Bachelor of Science in Hospitality Management (BSHM) and Bachelor of Science in Tourism Management (BSTM) which are decided and chosen by the researchers because of the educational tours background and experiences in travels. According to the advice of the Statistician the study will use a non-probability sampling of 100 respondents from the total sampling frame/population size of the first year to third year college students of the CTHM department counts to 601 students. The researchers will use a purposive sampling method for the reason that the selected respondents are qualified and applicable for the study based on the judgement of the researchers, wherein CTHM students are the population that are of interest.

The research will be conducted online with the use of social media platforms (e.g., Facebook and/or messenger) as a distribution method. The researchers came up with the survey questionnaire, wherein protocols issued by the IATF, DOT, and DOH are incorporated in the push and pull factors to know and understand the motivational factors that affects the willingness of the respondents to travel during this time of pandemic. Based on the approval of the thesis adviser and statistician, the survey questionnaire will be distributed through the use of Google Survey forms and will be utilized as a data collection tool. Moreover, the survey questionnaire will be disseminated by the researchers themselves and with the help of their friends and/or classmates to reach the specified respondents. The distribution of the online survey questionnaire through social media platforms will happen on the weekends (Saturday and Sunday) of March 2021 to April 2021 in the afternoon to consider the class hours of the CTHM department students of the university. In addition, as per the advice of the statistician, the researchers need to conduct a pretest on at least 30 respondents, which they distributed last March 11, 2021, to check the reliability of the survey questionnaire. Through the use of Cronbach's Alpha, the result of the pretest shows that it is greater than 0.70, which means the instrument used is valid and reliable.

The answers from the respondents will automatically be compiled in the respective email used to create the online survey questionnaire. The researchers will then collect the data of every respondent by manually checking the survey forms and listing all the results that are obtained from the questionnaires. After listing all the data, the researchers will use descriptive statistics and a nonparametric test for data analysis. The data will be processed and analyzed using mean, frequency, percentage, standard deviation, and chi-square test to summarize the results and present the findings based on the information gathered. Researchers will use a table to represent the answers of the respondents to easily determine the final results.

\section{ReSUlts AND Discussions}

This study aims to answer the research questions on demographic profile of respondents in terms of age, gender, year/level, number of trips per year, willingness to travel amidst the pandemic, willingness to travel to Boracay, and intended number of nights to stay in a destination. Moreover, the assessments of the respondents in terms of push and pull travel motivation factors and its relationship to the profile of the respondents would be elaborated. The researchers had a total of 116 respondents and the results will be discussed in this section. 


\section{Demographic Profile Of The Respondents}

Table1. Age of the Respondents

\begin{tabular}{|l|l|l|}
\hline Age & Frequency & Percentage \\
\hline $16-18$ & 9 & 7.8 \\
\hline $19-21$ & 95 & 81.9 \\
\hline $22-21$ & 10 & 8.6 \\
\hline 25 and above & 2 & 1.7 \\
\hline Total & $\mathbf{1 1 6}$ & $\mathbf{1 0 0 . 0}$ \\
\hline
\end{tabular}

In table 1, the results show that there is a large portion of respondents aged 19 to 21 years old that represent students who are in their 2nd or 3rd year of college at De La Salle University - Dasmarinas College of Tourism and Hospitality Management. To support this result, a study by ${ }^{[24]} N a s r a$ Shoka Kara and Kezia Herman Mkwizu (2020) stated that the sociodemographic factor age is considered as one of the factors that are mostly used. In the study, age is defined as the most crucial demographic factor wherein it affects their perspective in traveling as well as their desire to explore. It shows that the travel motivation of a person depends on their age, whereas people who are young tend to seek recreation or physical activities and novelty, while the older people prefer the opposite. It explains that the travel motivation of an individual varies depending on their age.

Table2. Gender of the Respondents

\begin{tabular}{|l|l|l|}
\hline Gender & Frequency & Percentage \\
\hline Female & 87 & 75.0 \\
\hline Male & 29 & 25.0 \\
\hline Total & $\mathbf{1 1 6}$ & $\mathbf{1 0 0 . 0}$ \\
\hline
\end{tabular}

Majority of the respondents as shown on Table 2 are classified as female $(75 \%)$ for the reason that most CTHM students studying at De La Salle University Dasmarinas are female. For this table, a research study conducted by ${ }^{[25]} \mathrm{Ma}$, A., et al., (2018) stated that men travel for business while women travel to have relaxation, shopping, and visit friends and relatives. Moreover, according to ${ }^{[261}$ Domecq \& Perez (2020), gender is prominent in other research studies that serves as a factor that suggests to consider the analytical and explanatory variables.

Table3. Year/Level of the Respondents

\begin{tabular}{|l|l|l|}
\hline Year/ Level & Frequency & Percentage \\
\hline 1st year & 38 & 32.8 \\
\hline 2nd year & 41 & 35.3 \\
\hline 3rd year & 37 & 31.9 \\
\hline Total & $\mathbf{1 1 6}$ & $\mathbf{1 0 0 . 0}$ \\
\hline
\end{tabular}

Moreover, the researchers included the year/level as part of the demographic profile because of the sampling frame used in this study, wherein the overall population was only specified to 1 st year to 3rd year students enrolled under the College of Tourism and Hospitality Management.

Table4. Number of trips per year of the Respondents

\begin{tabular}{|l|l|l|}
\hline Number of trips per year & Frequency & Percentage \\
\hline one & 43 & 37.1 \\
\hline two & 40 & 34.5 \\
\hline three to five & 31 & 26.7 \\
\hline six and above & 2 & 1.7 \\
\hline Total & $\mathbf{1 1 6}$ & $\mathbf{1 0 0 . 0}$ \\
\hline
\end{tabular}

Also, part of the demographic profile, there are $37.1 \%$ of the respondents who travel once a year. The researchers came to the conclusion that in an academic year, there is at least one tour included in the course of the respondents in accordance with the curriculum that the university has provided. According to ${ }^{[27]}$ Staffieri, S., et al., (2017) travelling is an opportunity for socialization, gaining knowledge, and being open-minded as they expose themselves to other places. As the young travelers "millennials" are exposed to traveling, it expands their perspective with better understanding, and lets them grow to be more open-minded, confident, flexible, and tolerant. The ${ }^{[28]}$ United Nations World Tourism Organization and World Youth Student and Educational Travel Confederation (2016) 
concludes that traveling is considered as a self-enhancing factor wherein it allows the travelers to escape and explore. Having that said, the researchers included the number of trips per year in the survey questionnaire to ensure that the chosen respondents had a travel history before or amidst the pandemic, for the reason that they determine further inputs which they can compare their previous experience and have a better response to the current travel situation.

According to an article released by ${ }^{[29]}$ Golden India Travel (2019) on why traveling is important for human life, they mentioned that the purpose of traveling is to explore new places, cultures, cuisines, rituals, and style of living. Through traveling, people could take a break from their everyday life, breathe from stress and restore their mental and physical health. There are different factors from an individual's daily routine that causes stress, anxiety, and depression to people. In addition, the current pandemic situation added fuel to the factors that could trigger people wherein they have restricted activities that could be done. Whereas the government slowly reopened tourism destinations which people could visit by complying with the necessary documents and guidelines.

Table5. Willingness to travel of the Respondents

\begin{tabular}{|l|l|l|}
\hline Willingness to travel & Frequency & Percentage \\
\hline No & 70 & 60.3 \\
\hline Yes & 46 & 39.7 \\
\hline Total & $\mathbf{1 1 6}$ & $\mathbf{1 0 0 . 0}$ \\
\hline
\end{tabular}

As Table 5 suggests, the majority of the respondents answered no (60.3\%) in traveling amidst the pandemic for the reason that it creates more risks of getting the virus than just staying at home ${ }^{[30]} \mathrm{Luo}$ and Lam (2020) agree that traveling to any destination involves risk and uncertainty. In this sense, people developed fear and travel anxiety that can be obtained from different factors such as individuals' risk perception. The power of media also influences people's behavior and point of view in which being exposed to false information from various local or international sources and the news about COVID-19 infection rate causes a rise in fear and anxiety ${ }^{[30]}$ (Luo and Lam, 2020).

Table6. Travel to Boracay of the Respondents

\begin{tabular}{|l|l|l|}
\hline Travel to Boracay & Frequency & Percentage \\
\hline No & 1 & .9 \\
\hline Yes & 115 & 99.1 \\
\hline Total & $\mathbf{1 1 6}$ & $\mathbf{1 0 0 . 0}$ \\
\hline
\end{tabular}

The idea of traveling to Boracay Island was asked to the respondents through the survey questionnaire and almost all (99.1\%) of them answered yes, as can be seen on Table 1.6. This is due to the fact that the question is built in a general form, wherein the researchers aim to know whether the respondents would want to visit Boracay Island in the middle of a pandemic or even after the COVID-19 outbreak. In addition, Boracay Island is one of the best destinations to go to in the Philippines as it offers fine white sand beaches with turquoise clear water and various activities, such as water sports, nightlife, and great food experiences. According to ${ }^{[311}$ Hamilton (2020), Boracay ranks $18^{\text {th }}$ in the Big 7 Travel's list of the 50 Most Beautiful Places in the World, in which, Philippines Tourism Secretary Bernadette Romulo-Puyat stated that it will encourage more people in regaining their certainty to travel and help tourism industry to recover from the drastic effects of the pandemic ${ }^{[32]}(D O T, 2020 c)$.

Table7. Duration of stay of the Respondents

\begin{tabular}{|l|l|l|}
\hline Duration & Frequency & Percentage \\
\hline 2 to 3 nights & 33 & 28.4 \\
\hline 4 to 5 nights & 56 & 48.3 \\
\hline 6 to 7 nights & 19 & 16.4 \\
\hline 8 nights and above & 8 & 6.9 \\
\hline Total & $\mathbf{1 1 6}$ & $\mathbf{1 0 0 . 0}$ \\
\hline
\end{tabular}

As Table 7 shows, the chosen duration of the respondents in a destination specifically in Boracay differs. However, the majority of them preferred 4 to 5 nights (48.3\%) of stay. It is because a span of 4 to 5 nights stay is the most convenient particularly with the situation that the world is experiencing right now from the pandemic, wherein direct contacts with other people are given a massive focus to 
avoid getting infected by the virus. ${ }^{[33]}$ Wright (2019) claimed that having at least a four-day weekend or a mini-vacation is already an adequate time for individuals to acquire the rest they needed from workloads and such. He also added that taking a mini vacation renews energy, resets the mind, rewards hard work, reconstructs goals, recaptures youth, reduces stress, refocuses priorities, and reconnects with loved ones ${ }^{[33]}$ (Wright, 2019).

\section{Assessment Of The Respondents About Their Push And Pull Travel Motivation}

Table8. Assessment of the respondents about their push travel motivators

\begin{tabular}{|c|c|c|c|c|}
\hline PUSH TRAVEL MOTIVATORS & Mean & Standard Deviation & Interpretation & Rank \\
\hline \multicolumn{5}{|l|}{ I am motivated to... } \\
\hline 1. Travel amidst the pandemic & 2.310 & .9905 & Disagree & 10 \\
\hline $\begin{array}{l}\text { 2. Travel once in a while to have some } \\
\text { rest/relaxation time for myself even if it } \\
\text { means to travel during a pandemic. }\end{array}$ & 2.741 & .9879 & Agree & 8 \\
\hline $\begin{array}{l}\text { 3. Travel to Boracay Island because of the } \\
\text { scenic view it offers, which makes me feel } \\
\text { at peace. }\end{array}$ & 3.448 & .6639 & Agree & 2 \\
\hline $\begin{array}{l}\text { 4. Travel to Boracay Island amidst the } \\
\text { pandemic as long as it is with my family } \\
\text { members and/or relatives. }\end{array}$ & 2.776 & 1.0222 & Agree & 7 \\
\hline $\begin{array}{l}\text { 5. Take extra precautions regarding my } \\
\text { personal hygiene when traveling to } \\
\text { Boracay Island. }\end{array}$ & 3.526 & .6784 & Strongly Agree & 1 \\
\hline $\begin{array}{l}\text { 6. Have a short-term stay ( } 2-3 \text { nights stay) } \\
\text { in my visit to Boracay Island. }\end{array}$ & 3.086 & .8604 & Agree & 4 \\
\hline $\begin{array}{l}\text { 7. Go through all the processes needed } \\
\text { (documents and RT-PCR test) before } \\
\text { traveling to Boracay Island. }\end{array}$ & 3.164 & .9775 & Agree & 3 \\
\hline $\begin{array}{l}\text { 8. Travel to Boracay Island amidst the } \\
\text { pandemic for the reason of visiting my } \\
\text { friends and/or family members living } \\
\text { there. }\end{array}$ & 2.319 & 1.1159 & Disagree & 9 \\
\hline $\begin{array}{l}\text { 9. Visit Boracay because the Island is not } \\
\text { crowded and only allows limited tourists } \\
\text { because of pandemic. }\end{array}$ & 2.888 & .9489 & Agree & 5 \\
\hline $\begin{array}{l}\text { 10. Travel to Boracay Island to explore } \\
\text { new things that may have changed amidst } \\
\text { the pandemic. }\end{array}$ & 2.793 & 1.0174 & Agree & 6 \\
\hline Overall & 2.905 & .6625 & Motivated & \\
\hline
\end{tabular}

The next area under investigation is the assessment of the respondents about travel motivations. The researchers modified the motivational factors included in their 4-point Likert Scale questionnaire, wherein it was structured in a way that it is associated with the government's protocols of fighting the spread of the coronavirus in relation to their study. The result shows that the respondents are more motivated to take extra precautions regarding their personal hygiene when traveling to Boracay Island. This motivator ranks as the highest variable as seen on Table 8. People nowadays prioritize their health and safety because of the fear of contracting the virus. They become conscious about their surroundings and their personal health and well-being. According to ${ }^{[34]}$ Glick, Blumenthal, and Baker (2020), travelers and/or consumers feel more secure when they know that the employees of the different establishments that they will have contact with, are wearing personal protective equipment (PPE) and have had third-party certified sanitation reviews. The result of push travel motivators in Table 8 also shows that the respondents disagreed to travel amidst pandemic as ranked the lowest, wherein the respondents are afraid to travel because it is still not safe. According to ${ }^{[35]}$ Cahyanto et al., (2016), the fear of infection and high risk of transmitting the virus from one person to another, use of transit, and influence based on the risk of infection in the destination are the factors to consider before travelling during this time of pandemic. In general, traveling is restricted during the pandemic, in which the government officials need to control the outbreak of the virus and implement preventive measures ${ }^{[36] \mid[37]}$ (Muley et al., 2020 and Jones et al., 2020). People have different demands in terms of traveling even during a pandemic, such as traveling for leisure, health purposes, business, and other 
essential jobs that provide basic goods and services. The ${ }^{[38]}$ IATF (2020b) categorized these travelers as APOR (Authorized Person Outside of Residence), which is used to identify the people who can travel around during this time of pandemic without passes. Push Travel Motivators are the internal factors that affect the decision of the respondents to travel amidst the pandemic. Based on the answers gathered from the respondents, the push motivators show that the respondents are motivated to travel, as the overall mean resulted in 2.905 and interpreted as motivated

Table9. Assessment of the respondents about their pull travel motivators

\begin{tabular}{|c|c|c|c|c|}
\hline $\begin{array}{l}\text { PULL TRAVEL MOTIVATORS } \\
\end{array}$ & Mean & Standard Deviation & Interpretation & Rank \\
\hline \multicolumn{5}{|l|}{ I am motivated to... } \\
\hline $\begin{array}{l}\text { 1. Travel to Boracay Island to enjoy the } \\
\text { permitted activities offered at a reduced } \\
\text { capacity, such as parasailing, kitesurfing, } \\
\text { and more. }\end{array}$ & 3.009 & .9371 & Agree & 8 \\
\hline $\begin{array}{l}\text { 2. Pay more than the usual price for my stay } \\
\text { in Boracay Island knowing that they ensure } \\
\text { the safety and security of the tourist. }\end{array}$ & 2.836 & 1.0039 & Agree & 9 \\
\hline $\begin{array}{l}\text { 3. Pre-book my accommodation in DOT } \\
\text { accredited hotels and resorts when visiting } \\
\text { Boracay Island. }\end{array}$ & 3.189 & .8569 & Agree & 2 \\
\hline $\begin{array}{l}\text { 4. Travel to Boracay because the local } \\
\text { government has lifted the age restriction of } \\
\text { tourists. }\end{array}$ & 2.690 & 1.0079 & Agree & 10 \\
\hline $\begin{array}{l}\text { 5. Ride tricycles and/or e-trikes during my } \\
\text { stay in Boracay Island as long as they } \\
\text { observe a No facemask + No face shield = } \\
\text { No Ride for all PUVs. }\end{array}$ & 3.026 & 1.0169 & Agree & 7 \\
\hline $\begin{array}{l}\text { 6. Visit Boracay Island amidst the pandemic } \\
\text { as long as I have the e-copy and/or printed } \\
\text { copy of my Health Declaration Card (HDC) } \\
\text { and Tourist QR Code that was given and } \\
\text { approved by the province's LGUs. }\end{array}$ & 3.129 & .9281 & Agree & 3.5 \\
\hline $\begin{array}{l}\text { 7. Travel to Boracay Island knowing that the } \\
\text { restaurants and/or attractions have 1-meter } \\
\text { social distancing signs, posters, or floor } \\
\text { stickers. }\end{array}$ & 3.086 & .9378 & Agree & 6 \\
\hline $\begin{array}{l}\text { 8. Travel knowing the employees are } \\
\text { following the minimum health protocols } \\
\text { imposed by the IATF. }\end{array}$ & 3.129 & .9467 & Agree & 3.5 \\
\hline $\begin{array}{l}\text { 9. Travel to Boracay Island amidst } \\
\text { pandemic given that they encourage a } \\
\text { contactless payment to observe social } \\
\text { distancing and lessen possible transmission. }\end{array}$ & 3.224 & .9145 & Agree & 1 \\
\hline $\begin{array}{l}\text { 10. Travel to Boracay given the safety } \\
\text { protocols issued by the LGU, DOT and } \\
\text { IATF are enough. }\end{array}$ & 3.129 & .9281 & Agree & 5 \\
\hline Overall & 3.046 & .7679 & Motivated & \\
\hline
\end{tabular}

4.51-5.00 Strongly Agree, 3.51-4.00 Agree, 2.51-3.50 Undecided, 1.51-2.50 Disagree, 1.00-1.50 Strongly Disagree

In Table 9, the result shows that the respondents are more motivated if Boracay Island encourages a contactless payment to observe social distancing that may lessen possible transmission during their trip amidst the pandemic, which ranks as the highest variable under the pull travel motivators. Study says that the compliance on various preventive measures against coronavirus such as thorough and frequent hand washing can decelerate the development of new COVID-19 cases ${ }^{\text {[39] }}$ (Harvard Health Publishing, 2021) since putting into habit the basic daily washing of hands is one of the most effective ways to avoid the spread of germs and viruses ${ }^{[401}$ (Warigon, 2020). In addition to these, the ${ }^{[411}$ Department of Tourism (2020d) requires that the establishment have a Certificate of Authority to operate; it ensures not only the safety of probable guests but also, the employees as well. However, the result in Table 9 also shows a minimum motivational response to travel to Boracay in line with the 
local government lifting the age restriction of tourists. It ranked lowest, but is still interpreted as motivated because most of the respondents are more concerned with the health and safety protocols that the destination has than the lifting of age restriction. The IATF and local governments lifted the age restrictions of the destination in order to boost its tourism and economic activity to encourage tourists of all ages to travel to Boracay amidst the COVID-19 ${ }^{[42]}(C N N, 2020)$. Pull Travel Motivators are the external factors that affect the decision of the respondents to travel amidst the pandemic. Based on the answers gathered from the respondents, the pull motivators show that the respondents are motivated to travel, as the overall mean resulted in 3.046 and interpreted as motivated.

\section{Relationship Between Demographic Profile And Travel Motivators}

Table10. Assessment of the respondents about their Travel Motivators

\begin{tabular}{|c|c|c|c|c|c|}
\hline \multicolumn{6}{|c|}{ PUSH MOTIVATORS } \\
\hline Demographic & Chi-square value & df & p-value & Interpretation & Implications/Remarks \\
\hline Age & 3.25 & 9 & 0.954 & Not Significant & $\begin{array}{l}\text { The push motivators are } \\
\text { not dependent on age. }\end{array}$ \\
\hline Gender & 1.204 & 3 & 0.752 & Not Significant & $\begin{array}{l}\text { The push motivators are } \\
\text { not dependent on gender. }\end{array}$ \\
\hline Year/Level & 4.87 & 6 & 0.56 & Not Significant & $\begin{array}{ll}\text { The push motivators are } \\
\text { not dependent on } \\
\text { year/level } & \\
\end{array}$ \\
\hline $\begin{array}{l}\text { Number of } \\
\text { trips per year }\end{array}$ & 3.75 & 9 & 0.927 & Not Significant & $\begin{array}{l}\text { The push motivators are } \\
\text { not dependent on the } \\
\text { number of trips per year. }\end{array}$ \\
\hline $\begin{array}{l}\text { Willingness to } \\
\text { travel }\end{array}$ & 53.572 & 3 & 0.00 & Significant & $\begin{array}{l}\text { The push motivators } \\
\text { depend on the willingness } \\
\text { to travel }\end{array}$ \\
\hline $\begin{array}{ll}\text { Willingness } & \text { to } \\
\text { travel } & \text { to } \\
\text { Boracay } & \end{array}$ & 1.12 & 3 & 0.77 & Not Significant & $\begin{array}{l}\text { The push motivators are } \\
\text { not dependent on the } \\
\text { willingness to travel to } \\
\text { Boracay. }\end{array}$ \\
\hline Duration & 6.65 & 9 & 0.673 & Not Significant & $\begin{array}{l}\text { The push motivators are } \\
\text { not dependent on the } \\
\text { duration of stay. }\end{array}$ \\
\hline
\end{tabular}

The relationship between the demographic profile and travel motivators varies. Based on Table 10, it shows that the respondents' age $(\mathrm{p}=0.954)$, gender $(\mathrm{p}=0.752)$, year/level $(\mathrm{p}=0.56)$, number of trips per year $(\mathrm{p}=0.927)$, willingness to travel to Boracay $(\mathrm{p}=0.77)$, and preferred duration of stay in a destination $(\mathrm{p}=0.673)$ were not associated on how they are influenced by their internal desires (push motivation) to travel. For instance, the willingness of an individual to travel for relaxation and leisure, is not because it is what the common for their age, gender, and educational year/level or it is the general thing to do in terms of their travel background, chosen length of stay in a destination, and willingness to visit a specific place. It is because individuals can decide what they want to do or where they want to go, whether or not they are included in the demographic profile mentioned above. Contrarily with this, the respondents' willingness to travel in general $(\mathrm{p}=0.00)$ has a connection with their internal motivation as shown in Table 10. Since one's willingness to travel can be determined through their travel motivators. However, the respondents' inner desires (push motivation) indicate no correlation regarding their age $(\mathrm{p}=0.504)$, gender $(\mathrm{p}=0.075)$, year/level $(\mathrm{p}=0.428)$, number of trips per year $(\mathrm{p}=0.552)$, and willingness to travel to Boracay $(\mathrm{p}=0.634)$.

Table11. Assessment of the respondents about their Travel Motivators

\begin{tabular}{|l|l|l|l|l|l|}
\hline PULL MOTIVATORS \\
\hline Demographic & Chi-square value & df & p-value & Interpretation & Implications/Remarks \\
\hline Age & 8.301 & 9 & 0.504 & Not Significant & $\begin{array}{l}\text { The pull motivators are } \\
\text { not dependent on age. }\end{array}$ \\
\hline Gender & 6.89 & 3 & 0.752 & Not Significant & $\begin{array}{l}\text { The pull motivators are } \\
\text { not dependent on gender. }\end{array}$ \\
\hline Year/Level & 5.955 & 6 & 0.428 & Not Significant & $\begin{array}{l}\text { The pull motivators are } \\
\text { not dependent on } \\
\text { year/level }\end{array}$ \\
\hline
\end{tabular}




\begin{tabular}{|l|l|l|l|l|l|}
\hline $\begin{array}{l}\text { Number of } \\
\text { trips per year }\end{array}$ & 7.819 & 9 & 0.552 & Not Significant & $\begin{array}{l}\text { The pull motivators are } \\
\text { not dependent on the } \\
\text { number of trips per year. }\end{array}$ \\
\hline $\begin{array}{l}\text { Willingness to } \\
\text { travel to }\end{array}$ & 35.97 & 3 & $\mathbf{0 . 0 0}$ & Significant & $\begin{array}{l}\text { The pull motivators } \\
\text { depend on the willingness } \\
\text { to travel }\end{array}$ \\
\hline $\begin{array}{l}\text { Willingness to } \\
\text { travel } \\
\text { Boracay to }\end{array}$ & 1.712 & 3 & 0.634 & Not Significant & $\begin{array}{l}\text { The pull motivators are } \\
\text { not dependent on the } \\
\text { willingness to travel to } \\
\text { Boracay. }\end{array}$ \\
\hline Duration & 22.814 & 9 & $\mathbf{0 . 0 0 7}$ & Significant & $\begin{array}{l}\text { The pull motivators are } \\
\text { dependent on the duration } \\
\text { of stay. }\end{array}$ \\
\hline
\end{tabular}

Found on Table 11, the relationship between the willingness to travel in general $(p=0.00)$ and preferred duration of stay in a destination $(\mathrm{p}=0.007)$ of respondents demonstrates a relevance. This is because most people nowadays are cautious about the services and quality of the places they go due to the pandemic, which affects the days/nights they decide to stay. Likewise, the respondents choose to stay for 4 to 5 nights to enjoy their time in the destination and make the most out of it. Aside from that, the Department of Tourism also encourages long stay tourists on Boracay Island. Nevertheless, the respondents' exterior inclination to travel is similar to their inner desires (push motivation) that indicates no correlation regarding their age $(p=0.504)$, gender $(p=0.075)$, year/level $(p=0.428)$, number of trips per year $(\mathrm{p}=0.552)$, and willingness to travel to Boracay $(\mathrm{p}=0.634)$.

\section{CONCLUSION}

The COVID-19 pandemic has radically affected the travel and tourism industry where people's lives and livelihoods are in great concern. This study reveals the alteration of tourists' preferences with the presence of the selected participants in terms of traveling to destinations specifically in Boracay Island. Majority of the respondents are females aged 19-21 who are mostly under the sophomore level in the university college. Most of the respondents travel once a year ranging from 4 to 5 nights duration of stay and they are willing to travel to Boracay in general, but they are not in favor of traveling amidst the pandemic. Their motivation varies from different internal and external factors, yet they are driven to travel to Boracay taking into consideration the safety of the destination and their personal health. Decisively, the demographic profile of the respondents and their travel motivators perceived to have no relationship.

Conclusively, the 1st year to 3rd year CTHM students of DLSU-D are not motivated to travel amidst this time of pandemic. In general, the respondents are afraid to travel due to the high risk of virus' transmission as well as the fear of other emerging COVID variants. However, they are willing to travel to Boracay in this time of pandemic as long as the health and safety protocols strictly imposed by the Government sectors are strictly observed by the tourists and locals. Dann's theory of push and pull has been used for this study as the basis to determine the factors that affect the travel preferences of tourists. Incorporating the health and safety protocols implemented by different travel agencies along with the push and pull travel motivators as a factor to help the researchers find out how willing the people are to travel to Boracay Island amidst pandemic given the current situation the country has. The demographic profile of the respondents has nothing to do in deciding the push and pull motivational factors that affect their preference when they travel. According to the results that the researchers have gathered, each person has their own unique characteristics and their own perspective to choose what they prefer, in a sense that the age bracket provided did not affect their preference in deciding which place to go or what activities they want to do. Even though the result of the survey conducted shows that most of them agree with the guidelines and protocols enforced by the IATF, WHO, DOH, DOT and DOTr. The respondents are afraid to risk their families' health and safety, rather than to accumulate the virus while traveling for the sake of leisure and recreation.

The government set restrictions to lessen the movement of people to control the transmission of the virus. This relates to the quarantine status of each municipality which however differs from one another and makes it harder to monitor. The inconsistency of the quarantine guidelines causes confusion to people. Therefore, the respondents are afraid to take the risk to travel even if they are motivated to travel given the guidelines set by different government agencies. The researchers 
concluded that during this period of time, news reports have mentioned that there is an increase in COVID cases, and the COVID-19 virus started to mutate, which scares the citizens of the country. The new coronavirus variants detected in the Philippines, added to the dilemma of the respondents that resulted in disinclination for them to travel.

The result of the study raises awareness that in a pandemic, most people will give more attention to their well-being particularly on their health, but they will also still be motivated to travel even with the various risks presented. This study recommends that several establishments in Boracay Island such as hotels and restaurants as well as the mode of transportation should ensure to utilize the basic protocols in avoiding the spread of the virus. For instance, a contactless process in different areas of an establishment, such as in the payment and information counter should be practiced. Moreover, a thorough disinfection of every area that guests and/or customers visit should be regularly sanitized.

This research suggests that each individual must maintain the required physical distance, wearing of facemask, proper hand washing and/or hand sanitizing outside or even at the comfort of their home so that safe travel will then be achieved sooner. This will also serve as a guide for the government to know what the tourists are looking for in order for them to be willing to travel amidst pandemic and if the safety protocols and guidelines are enough for the respondents to take risk and travel. In addition, the government could probably have an idea in what area they need to improve to encourage people to travel and boost the economy as they travel. Since the people could still experience the challenges of the COVID-19 pandemic, this study could help future researchers to expand the study. The guidelines and protocols are still developing to adapt to the new normal. Moreover, the focus of this study is to know how willing the people are to travel in the current situation of the country. This could help them to know the opinion of the respondents on what are the factors that encourage and hinders them to travel.

\section{REFERENCES}

[1] World Travel \& Tourism Council. (2019). Economic Impact Report. World Travel \& Tourism Council. https://wttc.org/Research/EconomicImpact\#: :text=In\%202019\%2C\%20Travel\%20\%26\%20Tourism's\%2 Odirect, $10 \% 20$ jobs\%20around $\% 20$ the $\% 20$ world

[2] WHO. (2020b, July 9). Transmission of SARS-CoV-2: implications for infection prevention precautions. World Health Organization. https://www.who.int/news-room/commentaries/detail/transmission-of-sarscov-2-implications-for-infection-prevention-precautions

[3] Martin, Y. (2020). How do SARS and MERS compare with COVID-19?. Medical News Today. https://www.medicalnewstoday.com/articles/how-do-sars-and-mers-compare-with-covid-19

[4] UNWTO. (2020a, April 16). COVID-19 Related Travel Restrictions a Global review for tourism. UNWTO. https://webunwto.s3.eu-west-1.amazonaws.com/s3fs-public/2020-04/TravelRestrictions_0.pdf

[5] UNWTO. (2020b, April 17). COVID-19 Response: 96\% of Global Destination Impose Travel Restrictions, UNWTO Reports. UNWTO. https://www.unwto.org/news/covid-19-response-travelrestrictions

[6] UNWTO. (2020c, December). Impact Assessment of the COVID 19 Outbreak on International Tourism. UNWTO. https://www.unwto.org/impact-assessment-of-the-covid-19-outbreak-on-international-tourism

[7] WHO. (2020a, April 1). Coronavirus disease 2019 (COVID-19) Situation Report - 72. World Health Organization. https://www.who.int/docs/default-source/coronaviruse/situation-reports/20200401-sitrep-72covid-19.pdf

[8] Congress of the Philippines. (2020, March 23). Republic Act No. 11469. Official Gazette. https://www.officialgazette.gov.ph/downloads/2020/03mar/20200324-RA-11469-RRD.pdf

[9] DOT. (2020a, October 1). Boracay reopens, heralds "safe, gradual" revival of Philippine Tourism. Local News. http://www.tourism.gov.ph/news_features/BoracayReopensHeraldsSafeGradualRevival.aspx

[10] DOT. (2020b, May 22). Health and Safety Guidelines Governing the Operations of Accommodation Establishments Under the New Normal. Health and Safety Guidelines. http://www.tourism.gov.ph/health andsafetyguidelinesnewnormal.aspx

[11] Yap, T. (October 9, 2020). Boracay tourist arrivals still low. Manila Bulletin https://mb.com.ph/2020/ 10/09/boracay-tourist-arrivals-still-low/

[12] Office of the Presidential Spokesperson. (2020a, September 24). IATF-EID Resolution No. 74. Official Gazette. https://www.officialgazette.gov.ph/downloads/2020/09sep/20200924-IATF-RESO-74-RRD.pdf

[13] Burgos, N. (December 25, 2020). Boracay arrivals breach 4,000 in December. Philippine Daily Inquirer Online.https://newsinfo.inquirer.net/1375659/boracay-arrivals-breach-4000-in-december 
[14] DOT 2021 (Feb 15, 2021) falsification http://tourism.gov.ph/news_features/ForgedCOVIDTestResults. aspx

[15] Zabal, B. (January 11, 2020). Boracay draws 2 million tourists in 2019. Panay News. https://www. panaynews.net/boracay-draws-2-million-tourists-in-2019/

[16] BMJ (2020). Coronavirus: covid-19 has killed more people than SARS and MERS combined, despite lower case fatality rate. https://doi.org/10.1136/bmj.m641

[17] Wachyuni, S., Kasumaningrum D. (2020). The Effect of COVID-19 Pandemic: How are the Future Tourist Behavior?. Journal of Education, Society and Behavioural Science. https://www.journaljesbs.com/index. php/JESBS/article/download/30219/56703

[18] Said, J. and Maryono, M. (2018). Motivation and Perception of Tourists as Push and Pull Factors to Visit National Park. E3S Web of Conferences, 31, 08022. E3S Conferences. https://doi.org/10.1051/e3 sconf/20183108022

[19] Roy, G., Sharma, S. (2020). Analyzing one-day tour trends during COVID-19 disruption - applying push and pull theory and text mining approach. Tourism Recreation Research. https://www.tandfonline.com /doi/pdf/10.1080/02508281.2020.1858614

[20] Zheng, D., Luo, Q., \& Ritchie, B. W. (2021). Afraid to travel after COVID-19? Self-protection, coping and resilience against pandemic 'travel fear.'. Tourism Management, 83. https://doi.org/10.1016/j.tourman. 2020.104261

[21] Yousaf, A., Amin, I., Santos, J., (2018). Tourist's Motivation to Travel: A Theoretical Perspective on the Existing Literature. ResearchGate. https://www.researchgate.net/publication/324903459_Tourist's_ Motivations_toTravel_A_Theoretical_Perspective_on_the_Existing_Literature

[22] Crompton, J. (1979). Motivations for pleasure vacation. ScienceDirect. https://www.sciencedirect.com/ science/article/abs/pii/0160738379900045?via\%3Dihub

[23] Zhang, J., Marcussen, C. (2007). Tourist motivation, market segmentation and marketing strategies. ResearchGate. https://www.researchgate.net/publication/255634551_Tourist_motivation_market_segment ation_and_marketing_strategies

[24] Kara, N., Mkwizu, K. (2020). Demographic factors and travel motivation among leisure tourists in Tanzania. Emerald insight. https://www.emerald.com/insight/content/doi/10.1108/IHR-01-2020-0002/full/ html

[25] Ma, A., Chow A., Cheung, L., Lee, K., Liu, S. (2018). Impacts of Tourists' Sociodemographic Characteristics on the Travel Motivation and Satisfaction: The Case of Protected Areas in South China. MDPI. https://www.mdpi.com/2071-1050/10/10/3388/htm\#B14-sustainability-10-03388

[26] Figueroa-Domecq, C., \& Segovia-Perez, M. (2020) Application of a gender perspective in tourism research: a theoretical and practical approach. Emerald Insight. https://www.emerald.com/insight/content/ doi/10.1108/JTA-02-2019-0009/full/html

[27] Staffieri, S., Cavagnaro, Elena., Rowson, Bill. (2017). Change as a travel benefit: Exploring the impact of travel experiences on the Italian youth. RHM. https://www.ajol.info/index.php/rhm/article/view/168521 $/ 157993$

[28] World Tourism Organisation and World Youth Student \& Educational Travel Confederation. (2016). Affiliate Members Global Reports, Volume 13 - The Power of Youth Travel. Madrid: United Nations World Tourism Organisation.https://www.e-unwto.org/doi/book/10.18111/9789284417162

[29] Golden India Travels. (2019, April 27). Why traveling is important for human life?. Golden India Travels. https://www.goldenindiatravels.com/blog/why-travelling-is-important-for-human-life

[30] Luo, J.M. and Lam, C.F. (2020, October 27). Travel Anxiety, Risk Attitude and Travel Intentions towards "Travel Bubble" Destinations in Hong Kong: Effect of the Fear of COVID-19. International Journal of Environmental Research and Public Health. https://www.ncbi.nlm.nih.gov/pmc/articles/PMC7672589/

[31] Hamilton, M. (2020, November). The 50 Most Beautiful Places in the World. Big Seven Media. https:// bigseventravel.com/50-most-beautiful-places-in-the-world/

[32] DOT. (2020c, October 30). Statement of the Department of Tourism on the inclusion of Palawan and Boracay in Big 7 Travel's list of 50 Most Beautiful Places. Media Release. http://www.tourism.gov.ph/ news_features/PalawanBoracayBig7TravelsList.aspx

[33] Wright, B. (2019, April 28). 8 Reasons Why Everyone Should Embrace the Mini-Vacation. Thrive Global Community. https://thriveglobal.com/stories/8-reasons-why-everyone-should-embrace-the-mini-vacation-

[34] Glick, J., Blumenthal, J., Baker, M. (2020). How to restore confidence in travel during an uncertain time. PwC US. https://www.pwc.com/us/en/industries/consumer-markets/library/how-to-restore-confidence-intravel-during-covid-19.html 
[35] Cahyanto, I., Wilblishauser, M., Pennington-Gray, L., Schroeder, A. (2016). The dynamics of travel avoidance: The case of Ebola in the U.S. ScienceDirect. https://www.sciencedirect.com/science/article /abs/pii/S2211973616300873

[36] Muley, D., Shahin, Md., Dias, C. Abdullah M. (2020). Roles of Transport during Outbreak of Infectious Diseases: Evidence from the past. MPDI. https://www.mdpi.com/2071-1050/12/18/7367/pdf

[37] Jones, C., Philippon, T., Venkateswaran, V. (2020). Optimal Mitigation Policies in a Pandemic: Social Distancing and Working from Home. National Bureau of Economic Research. https://www.nber.org/ papers/w26984

[38] IATF-EID. (2020b, October 15). Resolution No. 79. Official Gazette. https://www.officialgazette.gov.ph/ downloads/2020/10oct/20201015-IATF-Resolution-79-RRD.pdf

[39] Harvard Health Publishing. (2021, May 17). Preventing the spread of the coronavirus. The President and Fellows of Harvard College. https://www.health.harvard.edu/diseases-and-conditions/preventing-thespread-of-the-coronavirus

[40] Warigon, C. (2020, October 23). COVID-19 pandemic heightens the importance of handwashing with soap. WHO Africa. https://www.afro.who.int/news/covid-19-pandemic-heightens-importance-handwashin g-soap

[41] DOT. (2020d, June 10). IATF-EID Resolution Reiterates 'DOT Certificate of Authority' as Requisite to Operate. Department Of Tourism. http://www.tourism.gov.ph/news_features/DOTCertificateOfAuthority. aspx

[42] CNN Philippines Staff. (2020, October 16). Persons ages 15-65 allowed to go out as IATF eases quarantine age restrictions. CNN Philippines. https://www.cnn.ph/news/2020/10/16/Quarantine-agerestriction-15-to-65-years-old.html

Citation: Oabel, Kathlene Antonette SJ, et.al. "Tourists' Motivation to Travel to Boracay amidst COVID-19 Pandemic". International Journal of Research in Tourism and Hospitality (IJRTH), vol 7, no. 1, 2021, pp. 0114. doi: https://doi.org/10.20431/2455-0043.0702001.

Copyright: () 2021 Authors. This is an open-access article distributed under the terms of the Creative Commons Attribution License, which permits unrestricted use, distribution, and reproduction in any medium, provided the original author and source are credited. 